Journal of Epidemiology and Public Health (2017), 2(2): 142-153

https://doi.org/10.26911/jepublichealth.2017.02.02.05

\title{
Effects of Education, Nutrition Status, Treatment Compliance, Family Income, and Family Support, on the Cure of Tuberculosis in Mojokerto, East Java
}

\author{
Puspitasari1,2), Ambar Mudigdo3), Rita Benya Adriani4) \\ 1) Muhammadiyah University, Sidoarjo, East Java \\ 2)Masters Program in Public Health, Universitas Sebelas Maret \\ 3) Faculty of Medicine, Universitas Sebelas Maret \\ 4) Schoolof Health Polytechnics, Surakarta
}

\begin{abstract}
Background: Tuberculosis is an important global public health issue. Countries around the world have committed to control the disease with various programs. However, the cure of Tuberculosis treatment in many countries is still low, which can hamperthe success of Tuberculosis control program.Productivity of Tuberculosis patients continues to decrease that leads to socioeconomic burden. This study aimed to examinethe effects of education, nutrition status, treatment compliance, family income, and family support, on the cure of Tuberculosis.

Subjects and Method: This was an observational analytic study with case control design. The study was conducted in Mojokerto, East Java, from April to May, 2017. A total sample of $108 \mathrm{Tu}-$ berculosis patients were selected for this study by fixed disease sampling. The sample consisted of 35 uncured cases of Tuberculosis and 73 cured cases of Tuberculosis. The dependent variable was cure of Tuberculosis. The independent variables were education, nutrition status, treatment compliance, family income, and family support. The data was collected by a set of questionnaire and analyzed using path analysis.

Results: Nutritional status $(b=1.31 ; 95 \% \mathrm{CI}=0.41$ to $2.22 ; \mathrm{p}=0.004)$ and treatment compliance $(\mathrm{b}=1.07 ; 95 \% \mathrm{CI}=0.17$ to $1.97 ; \mathrm{p}=0.019)$ directly and positively affect the cure of Tuberculosis. Nutritional status was affected by high education ( $b=1.62 ; 95 \% \mathrm{CI}=0.62$ to $2.63 ; \mathrm{p}=0.002)$, family income $(b=1.66 ; 95 \% \mathrm{CI}=0.70$ to $2.62 ; \mathrm{p}=0.001)$, and strong family support $(\mathrm{b}=1.50 ; 95 \% \mathrm{CI}=0.36$ to $2.63 ; \mathrm{p}=0.010)$. Treatment compliance was affected by high education $(\mathrm{b}=0.84 ; 95 \% \mathrm{CI}=-0.14$ to $1.81 ; \mathrm{p}=0.093)$, family income $(\mathrm{b}=1.36 ; 95 \% \mathrm{CI}=0.42$ to $2.30 ; \mathrm{p}=0.005)$, and strong family support $(\mathrm{b}=2.08 ; 95 \% \mathrm{CI}=0.96$ to $3.19 ; \mathrm{p}<0.001$ ).
\end{abstract}

Conclusion:Cure of Tuberculosis is directly affected by nutritional statusand treatment compliance.Education, family support, and family income, indirectly affect cure of Tuberculosis.

Keywords: cure of Tuberculosis, education, nutrition status, family income, family support, treatment compliance

\section{Correspondence:}

Puspitasari. Masters Program in Public Health, Sebelas Maret University, Jl. Ir. Sutami 36 A, Surakarta 57126, Central Java.Email: puspita9o@yahoo.co.id. Mobile: +6281333060714.

\section{BACKGROUND}

Tuberculosis (TB) is an infectious disease caused by the bacterium Mycobacterium tuberculosis and can be transmitted directly (Nurmadya et al., 2015). Mycobacterium tuberculosis bacteria can infect tissues, especially lung tissue. Of all TB cases the most commonly found are pulmonary $\mathrm{TB}$ while extrapulmonary TB occupies a small portion (Muna and Soleha, 2014). Lately TB has been among the top 10 causes of death in the world (WHO, 2017).

Various efforts were made to alleviate this problem, including, through the Millennium Development Goals (MDGs) which consisted of 8 goals and to combat TB pro- 
blems in the 6th objective, especially $6 \mathrm{C}$, namely controlling the spread and starting to reduce new cases of malaria and other major diseases until 2015 and the target to control TB has been achieved (WHO, 2014).

The Pakistan Development Goals (SDGs) continue the program of the MDGs which consists of 17 goals and one of the third goals is to end the tuberculosis epidemic by 2030 (WHO, 2015). Another strategy to overcome TB problems, namely The End TB Strategy which has a target that by the year of 2035, it has decreased TB incidence by $90 \%$ and a $95 \%$ reduction in $\mathrm{TB}$ deaths (WHO, 2017).

In 2015, the incidence of TB cases in the world was 10.4 million and cases of deaths reached 1.8 million including 0.4 million people with TB with HIV (WHO, 2017). The case of TB in the world in 2015 was $60 \%$ in 6 countries and one of them was Indonesia (WHO, 2017). The prevalence of pulmonary TB in Indonesia is still the same as in 2007, which is $0.4 \%$ of all diseases in Indonesia (Ministry of Health, 2013).

East Java Province in 2014 ranked eighth out of 33 provinces in Indonesia for the discovery of positive smear cases with a total of 21,036 sufferers. Data on patients treated in 2013 found that TB cure rates in East Java had reached a predetermined target of $85 \%$. There are several regions in East Java that have cure rates for positive smear pulmonary TB below the predetermined target, among them the lowest cure rate is Batu, which is $54.10 \%$, then Sampang district with a cure rate of $63.38 \%$, and Mojokerto city which has numbers recovery of $63.46 \%$ (East Java Health Office, 2015).

Mojokerto City has the highest population density of 7577.10 per $\mathrm{km} 2$ while the population density of Batu city is 997.58 per $\mathrm{km} 2$ and the population density of the city of Sampang is 750.76 per $\mathrm{km} 2$ (East
Java Health Office, 2015). High population density causes pulmonary TB problems in the city of Mojokerto to be addressed immediately in order for it not to spread more.

Data of positive smear pulmonary TB patients' amount to 104 cases treated in 2013 , it was also obtained of $30.78 \%$ for patients who underwent complete treatment of $1.92 \%$ for patients who dropped out of treatment of $1.92 \%$ for patients who moved, while patients who died were $1.92 \%$. In 2014, there were 107.46 cases of positive smear in the city of Mojokerto per 100,000 inhabitants (Mojokerto City Health Office, 2015).

In 2014, there were more pulmonary TB patients in the city of Mojokerto who underwent treatment at the Hospital, which amounted to $66 \%$, while TB patients who underwent treatment at the health center were $34 \%$. Patients with pulmonary TB with positive smear were $12.69 \%$ aged 15 -24 years, $22.39 \%$ aged 25-34 years, $17.16 \%$ aged 35-44 years, 22.39\% aged 45-54 years, $17.16 \%$ aged $55-65$ years, and $8.21 \%$ over 65 years old (Mojokerto City Health Office, 2015).

The 2013 Basic Health Research Report showed that the prevalence of pulmonary TB tended to increase with increasing age, in low education, not working (Ministry of Health, 2013). The purpose of this study is to analyze the influence of education level, family income, nutritional status, family support, and medication adherence to the cure of pulmonary TB treatment in Mojokerto City.

\footnotetext{
SUBJECTS AND METHOD

1. Study Design

This was observational analytic study. The design used was case control. It was conducted in the area of Mojokerto City, East Java Province from April to May 2017.
} 
Journal of Epidemiology and Public Health (2017), 2(2): 142-153

https://doi.org/10.26911/jepublichealth.2017.02.02.05

\section{Population and Sampling}

The target population in this study was positive smear pulmonary $\mathrm{TB}$ patients who were treated in the Mojokerto City area. Source population in this study were positive smear pulmonary TB patients who had completed treatment for category I in the Mojokerto City area in the period January 2015 to December 2015.

The sample in this study consisted of two types namely case samples and control samples. Case samples were positive smear pulmonary TB patients who had completed treatment for category I in Mojokerto City area and were declared as not cured in the period January 2015 to December 2015. Control samples were positive smear pulmonary TB patients who had completed treatment for category I in Mojokerto City area and stated during the period of January 2015 to December 2015.

Case samples have inclusion criteria, including, patients aged $\geq 18$ years and $\leq 60$ years, patients with complete and failed treatment results, patients who can be traced. The exclusion criteria from the sample cases were those who refused to take part in the study, underwent pulmonary TB treatment, died during treatment for any reason, and had changed addresses.

The control sample has inclusion criteria, namely patients aged $\geq 18$ years and $\leq 60$ years of the year and those who can be traced, while the exclusion criteria are patients who have changed addresses, and patients who are declared cured but refuse to take the study.The sampling technique used in this study is fixed disease sampling, namely the sampling scheme based on the status of the disease under study, while the exposure status of the subject varied according to the status of the disease. The sample used was 108 subjects consisting of 35 case subjects and 73 control subjects.

\section{Study Variables}

The dependent variables were education leel, family income and family support. Intermediate variables are nutritional status and treatment compliance. Independent variable was healing.

\section{Operational Definition of Variables} Education level was the last formal education level taken by pulmonary TB patients based on the last diploma they have.

Family income was income that is used as a source of the family's economy for 1 month.

Family support was the statement of the study subject to the support given by family members in dealing with pulmonary TB disease suffered by patients;

Nutritional status was the nutritional status of pulmonary TB patients while undergoing pulmonary TB treatment as measured by the Body Mass Index (BMI).

Medication adherence was the behavior of patients in accordance with the provisions given by health personnel, namely routinely coming to the health center or hospital, checking their phlegm regularly and regularly taking medication.

Healing was declared cured if the re-examination of phlegm is two times a negative BTA result.

\section{Study Instruments}

The type of data collected is primary data and secondary data. The primary data used include the level of education, family income, family support, and treatment compliance. Secondary data used include height and weight of pulmonary TB patients to measure nutritional status through BMI and also records from Puskesmas or hospitals that declared as recovered/cured or did not recover/cured.

Based on the results of the item-total correlation reliability test, it was found that the measurement of family support variables and adherence to treatment counted C 
0.20, and Cronbach's Alpha $\geq 0.70$, so that all questions were declared reliable. The results of the questionnaire reliability test can be seen in Table 1.

\section{Data Analysis}

The analysis model used is path analysis using the STATA 13 program.

Table 1.Reliability test results

\begin{tabular}{lcc}
\hline \multicolumn{1}{c}{ Variable } & Item Total Correlation (r) & Alpha Cronbach \\
\hline Family Support & $\geq 0.26$ & 0.86 \\
Treatment Compliance & $\geq 0.21$ & 0.78 \\
\hline
\end{tabular}

\section{RESULTS}

The characteristics of the study subjects were seen according to age, gender, and occupation. Table 2 shows that from 108 study subjects, $20.4 \%$ were $18-25$ years old, $14.8 \%$ were $26-35$ years old, $15.7 \%$ were $36-45$ years old, and $49.1 \%$ were $46-60$ years old; male gender by $60.2 \%$ and female by $39.8 \%$; pulmonary TB sufferers $26.9 \%$ did not work, $12.0 \%$ were laborers, $42.6 \%$ were private, $15.7 \%$ were self-employed, and $2.8 \%$ worked as civil servants.

Table 2. Characteristics of study subjects

\begin{tabular}{llll}
\hline Characteristics & \multicolumn{1}{c}{ Criteria } & n & \% \\
\hline Age & 18-25y.o & 22 & 20.4 \\
& $26-35$ y.o & 16 & 14.8 \\
& 36-45 y.o & 17 & 15.7 \\
Gender & $46-60$ y.o & 53 & 49.1 \\
& Male & 65 & 60.2 \\
Occupation & Female & 43 & 39.8 \\
& Jobless & 29 & 26.9 \\
& Labor & 13 & 12.0 \\
& Private & 46 & 42.6 \\
& Entrepreneur & 17 & 15.7 \\
\hline
\end{tabular}

Table 4 shows that the level of high education ( $\mathrm{OR}=3.15, \mathrm{p}=0.006)$, high family income $(\mathrm{OR}=1.22, \mathrm{p}=0.629)$, strong family support (OR $=67.41, \mathrm{p}<0.001)$, good nutritional status (OR $=4.74, \mathrm{p}<0.001)$, and medication adherence $(\mathrm{OR}=3.92, \mathrm{p}=$ o.oo1) had a positive influence on the cure of pulmonary TB treatment.

Figure 1 shows the structural model after the estimation using STATA 13, it
The results of the frequency distribution of study variables which included recovery status, education level, family income, nutritional status, family support, and medication compliance can be seen in Table 3 .

Table 3 shows that most pulmonary TB patients in Mojokerto City have a high level of education (63.9\%), low family income (50.9\%), strong family support (73.1\%), good nutritional status (56.5\%), and adherent treatment (59.3\%). isobtained path coefficient value between education of positive smear pulmonary TB patients with family income positive value 0.84 with $\mathrm{p}=0.041$ and is declared as statistically significant. The path coefficient value between education and the nutritional status of patients is positive of 1.6 with a value of $p=0.002$ and it is statistically significant. 
Journal of Epidemiology and Public Health (2017), 2(2): 142-153

https://doi.org/10.26911/jepublichealth.2017.02.02.05

Table 3. Univariate analysis of study variables

\begin{tabular}{lcc}
\hline \multicolumn{1}{c}{ Variable } & n & \% \\
\hline Healing Status & & \\
Not cured & 35 & 32.4 \\
Cured & 73 & 67.6 \\
Educational Background & & \\
Low (<SHS) & 39 & 36.1 \\
High ( $\geq$ SHS) & 69 & 63.9 \\
Family Income & & \\
Low (<Rp 1,437,500) & 55 & 50.9 \\
High ( $\geq$ Rp 1,437,500) & 53 & 49.1 \\
Family Support & & 26.9 \\
Weak & 29 & 73.1 \\
Strong & 79 & 43.5 \\
Nutritional Status & & 56.5 \\
Lack & 47 & 40.7 \\
Good & 61 & 59.3 \\
Treatment Compliance & & \\
No & 44 & \\
\hline
\end{tabular}

Table 4. Bivariate analysis of the influences of the level of education, family income, family support, nutritional status, and medication adherence to cure for pulmonary TB treatment.

\begin{tabular}{lcc}
\hline Independent Variable & OR & p \\
\hline Educational Background & 3.15 & 0.006 \\
Family Income & 1.22 & 0.629 \\
Family Support & 67.41 & $<0.001$ \\
Nutritional Status & 4.74 & $<0.001$ \\
Treatment Compliance & 3.92 & 0.001 \\
\hline
\end{tabular}

The path coefficient value between education and adherence to treatment is positive 0.84 with $\mathrm{p}=0.093$ and is statistically stated to be close to significant. The family income path coefficient value of nutritional status is positive 1.7 with $\mathrm{p}=0.001$ and is stated as statistically significant.

The family income path coefficient value for treatment compliance is positive $\mathbf{1 . 4}$ with $\mathrm{p}=0.005$ and is stated as sta tistically significant.The path value of family support coefficient on nutritional status is positive 1.5 with $\mathrm{p}=0.010$ and is stated as statistically significant.Family support path coefficient value for treatment compliance is positive 2.1 with $\mathrm{p}<0.001$ and is statistically significant. 


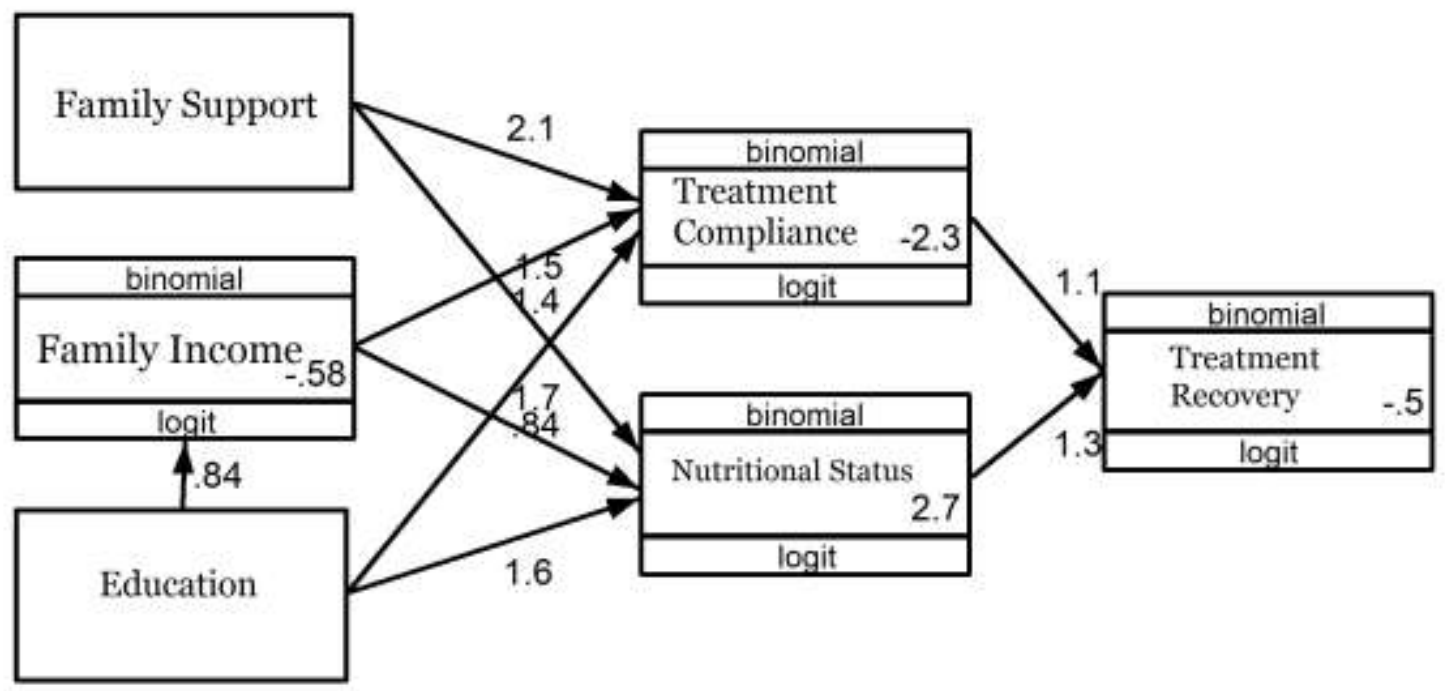

Figure 1. Path Analysis Structural Model

The result of path analysis of treatment compliance on treatment recovery was positive and the score was 1.1 with the score of $\mathrm{p}=0.019$ and it was statistically significant. The result of path coefficient of nutritional status on recovery treatment was positive and the score was 1.3 with the score of $\mathrm{p}=0.004$ and it was statistically significant.

Table 5 showed that treatment recoverywas directly affected by nutritional status and treatment compliance.

Good nutritional status has the logodd to recover by 1.31 point higher compared to poor nutritional status $(b=1.31 ; 95 \%$ $\mathrm{CI}=0.41$ to $2.22 ; \mathrm{p}=0.004$ ).

Pulmonary TB sufferers who have treatment compliance have the recovery logodd by 1.07 points greater than those who did not comply $(\mathrm{b}=1.07 ; 95 \% \mathrm{CI}=0.17$ to $1.97 ; \mathrm{p}=0.019$ ).

Nutritional status and treatment compliance was affected by educational level, family income, and family support.

High educational level has good nutritional status logoddby 1.62 point greater than low educational level $(b=1.62 ; 95 \%$ $\mathrm{CI}=0.62$ to $2.63 ; \mathrm{p}=0.002$ ).

High level of education has treatment compliance logodd by 0.84 point greater than low level of education $(b=0.84 ; 95 \%$ $\mathrm{CI}=-0.14$ to $1.81 ; \mathrm{p}=0.093$ ).

High family income has good nutritional status logodd by 1.66 than low family income $(b=1.66 ; 95 \% \mathrm{CI}=0.70$ to $2.62 ; \mathrm{p}=$ 0.001).

High family income has good treatment compliance logodd by 1.36 point greater than low family income $(b=1.36 ; 95 \%$ $\mathrm{CI}=0.42$ to $2.30 ; \mathrm{p}=0.005$ ).

Strong family support has good nutritional status logodd by 1.50 point greater than low family support $(\mathrm{b}=1.50 ; 95 \% \mathrm{CI}=$ 0.36 to $2.63 ; \mathrm{p}=0.010$ ).

Strong family support has the logodd of treatment compliance by 2.08 point greater than low family support $(b=2.08$; 95\% $\mathrm{CI}=0.96$ to $3.19 ; \mathrm{p}<0.001$ ).

Nutritional statusand treatment compliancehave a direct and positive effect on recovery, while educational level, family income, and family support have an indirect and positive effect. 
Journal of Epidemiology and Public Health (2017), 2(2): 142-153

https://doi.org/10.26911/jepublichealth.2017.02.02.05

Table 5. The Results of Path Analysis

\begin{tabular}{|c|c|c|c|c|c|c|}
\hline \multirow{2}{*}{\multicolumn{2}{|c|}{ Dependent Variables }} & \multirow[b]{2}{*}{$\begin{array}{l}\text { Independent } \\
\text { Variables }\end{array}$} & \multirow{2}{*}{$\begin{array}{l}\text { Path } \\
\text { Coeffici } \\
\text { ent }\end{array}$} & \multicolumn{2}{|c|}{$95 \%$ CI } & \multirow[b]{2}{*}{$\mathbf{p}$} \\
\hline & & & & $\begin{array}{l}\text { Lower } \\
\text { Limit }\end{array}$ & $\begin{array}{l}\text { Upper } \\
\text { Limit }\end{array}$ & \\
\hline \multirow{4}{*}{\multicolumn{2}{|c|}{$\begin{array}{l}\text { Direct Effect } \\
\text { Treatment Recovery }\end{array}$}} & & & & & \\
\hline & & Good Nutritional & & & & \\
\hline & & Status & 1.31 & 0.41 & 2.22 & 0.004 \\
\hline & & $\begin{array}{l}\text { Treatment } \\
\text { Compliance }\end{array}$ & 1.07 & 0.17 & 1.97 & 0.019 \\
\hline \multirow{4}{*}{$\begin{array}{l}\text { Indirect Effect } \\
\text { Good Nutritional } \\
\text { Status }\end{array}$} & & & & & & \\
\hline & & $\begin{array}{l}\text { Strong Family } \\
\text { Support }\end{array}$ & 1.50 & 0.36 & 2.63 & 0.010 \\
\hline & & $\begin{array}{l}\text { Family Income } \\
\geq \text { Rp } 1,437,500\end{array}$ & 1.66 & 0.70 & 2.62 & 0.001 \\
\hline & & Education $\geq \mathrm{HS}$ & 1.62 & 0.62 & 2.63 & 0.002 \\
\hline \multirow{4}{*}{$\begin{array}{l}\text { Treatment } \\
\text { Compliance }\end{array}$} & $\longleftarrow$ & Strong Family & 2.08 & 0.96 & 3.19 & $<0.001$ \\
\hline & & - Support & & & & \\
\hline & & $\begin{array}{l}\text { Family Income } \geq R p \\
1,437,500\end{array}$ & 1.36 & 0.42 & 2.30 & 0.005 \\
\hline & $<$ & Education $\geq \mathrm{HS}$ & 0.84 & -0.14 & 1.81 & 0.093 \\
\hline $\begin{array}{l}\text { Family Income } \\
\geq \mathrm{Rp} 1,437,500\end{array}$ & & Education $\geq$ HS & 0.84 & 0.03 & 1.65 & 0.041 \\
\hline Log Likelihood = & & -238.46 & & & & \\
\hline
\end{tabular}

\section{DISCUSSIONS}

1. The effect of educational level on recovery treatment of pulmonary TB in Mojokerto.

There was an indirect effect of educational level on recovery treatment of pulmonary TB patients in Mojokerto. The result of analysis showed thatthere was an indirect effect of educational level through intermediate variables which were nutritional status and treatment compliance. Educational level has a positive effect on nutritional status which was statistically significant. Educational level also has a positive effect on treatment compliance and it was statistically nearly significant.

The result of this study was supported by Purwaningrum and Wardani (2012) who stated thatthere was an indirect effect of educational level on nutritional status through food intake. Provision of balanced food intake was one of the determinants of successful treatment in pulmonary TB patients (Amaliah, 2012).
It can be concluded that high level of education was related to high knowledge as well, so it can affect pulmonary TB sufferers in determining appropriate foods to be consumed. Because good food intake would lead to good nutritional status.

The result of this study was also supported by Erawatyningsih et al., (2009) which stated that low level of patients' education would lead to less compliant for treatment because low education could affect the absorption in obtaining information so that it can also affect the understanding level of the disease, treatment of pulmonary $\mathrm{TB}$, and the dangers caused by not taking the medication regularly.

Low education lead to low knowledge, it caused the patients to stop the treatment because of their lack of knowledge and lack of understanding about the treatment that they did (Wirdani, 2000). High level of knowledge of pulmonary TB sufferers about the disease would make them to be more aware in doing the treatment for pulmonary 
Journal of Epidemiology and Public Health (2017), 2(2): 142-153

https://doi.org/10.26911/jepublichealth.2017.02.02.05

TB regularly (Nugroho, 2011). Knowledge was influenced by the level of education and the age of a person.

The result of this study was in contrary with a study done by Ruditya (2015) which stated that there was no relationship between educational level and treatment compliance of the patients in checking the sputum during the treatment.

It can be concluded that level of education wasrelated to knowledge. Lack of knowledge could lead to lack of informations and the patients would have poor understanding about the disease which was pulmonary TB so that they would not have good treatment compliance.

\section{The effect of family income on re- covery treatment of pulmonary TB in Mojokerto.}

There was an indirect effect of family income on recovery treatment of pulmonary TBpatients through nutritional status and treatment compliance. Family income has a positive effect on nutritional status and treatment compliance and it was statistically significant. High family income would increase patients' nutritional status and they would be more obedient in doing the treatment.

There was a relationship between income and nutritional status. The fundamental reason of nutritional problems was economic factors that influence the imbalance between food intake and the occurrence of infectious diseases (Phelan et al, 2010). Similar opinion was expressed by Purwaningrum and Wardani (2012) who suggested that nutritional status was influenced by food intake while food intake itself was influenced by several factors and one of them was family income. Family income was an important factor of the fulfillment of food quality and quantity (Adriani and Wirjatmadi, 2013).
The different result was shown by Tirtana (2011) which stated that there was no significant relationship between income and the success of treatment in pulmonary TB patients in the Central Java region.

There was a significant relationship between family income and the incidence of treatment outbreak. the incidence of treatment outbreakwas mostly happened in lowincome family (Silva et al, 2016).

The cause of health problems was economic differences. Low economy conditions would lead to the difficulties in doing prevention or treatment (Currie, 2005).

Erawatyningsih et al., (2009) stated that low family income would affectnoncompliance of pulmonary TB patients in doing the treatment. Family income was related to the recovery of patients with pulmonary TB. Patients with low income can decrease the chance to recover from pulmonary TB (Murtantiningsih and Wahyono, 2010).

It can be concluded that pulmonary TB patients who have low income would find problems in looking for transport costs for the treatment at health care facilities and buying nutritious food because the income received by the family has been used to fulfill basic daily needs, therefore, they consumed small amount of food. This could make the patients to not adhering to the treatment and decrease patient's nutritional status.

\section{The effect of family support on re- covery treatment of pulmonary $\mathrm{TB}$ in Mojokerto.}

There was an indirect effect of family support on recovery treatment of pulmonary TB patientsthrough nutritional status and treatment compliance. Family support has a positive effect on nutritional status and treatment compliance and it was statistically significant. High family support would lead to good patients' nutritional status and 
they would be more obedient to the treatment.

The result of this study was supported by a study done by Muna and Soleha (2014) which stated that social support both emotional and instrumental supports from the family could affect the regularity of pulmonary TB patients in taking the medication. High family support could lead to high treatment compliance of pulmonary TB patients in consuming OAT (Hutapea, 2009). The support provided can be in the form of giving enough attention, providing helps to fulfill daily needs, participating in monitoring, accompanying pulmonary $\mathrm{TB}$ patients to health services, and reminding them of eating and taking medication (Nagarkar et al, 2012).

Different study was shown by Nugroho (2011) which stated that pulmonary TB sufferers stopped the treatment even though they have good family support. This was because family support was not a strong reason to stop the treatment.

Family support was needed by pulmonary TB patients in determining nutritional status and treatment compliance. If TB patients have good family support, they would feel relieved, comfortable, more cared for and loved, feel their needs were fulfilled by their families, and were motivated to conduct the medication and taking the medicine as recommended by health personnels. Family support in the form of instrumental support can also influence good nutritional status. This was because the family provided nutritious food and was needed by the patients with pulmonary $\mathrm{TB}$ so that their nutritional status became better and support the recovery.

\section{The effect of nutritional status on recovery treatment of pulmonary TB in Mojokerto.}

There was a positive and direct effect of nutritional status on recovery treatment of pulmonary TB patients which was statistically significant. Good nutritional status would increase the likelihood of recovery.

Murtantiningsih and Wahyono (2010) stated that there was a relationship between nutritional status on recovery treatment of pulmonary TB patients which was statistically significant. Malnutrition can reduce the resistance to TB disease (Garcia et al, 2009).

There was a relationship between nutritional status on recovery treatment of pulmonary TB patients which was statistically significant. The patients were more likely to recover after they received nutritional intake during the treatment period compared to patients who did not get nutritional intake (Samuel et al, 2016). Food intake can affect a person's nutritional status (Purwaningrum and Wardani, 2012).

Different results of the study by Tirtana (2011) who stated that there was no significant relationship between nutritional status and treatment success of pulmonary TB patients in Central Java.

Poor nutritional status was a nutritional condition that showed the small amount of energy intake than the released energy. This could occur because the amount of energy intake was less than the individual needs which were recommended (Wardlaw, 2007).

It can be concluded that nutritional status could affect treatment recovery of pulmonary TB patients because good nutritional status could increasebody immunity so that it can be resistant to pulmonary $\mathrm{TB}$ disease, while poor nutritional status can inhibit the recovery process and could ease the recurrence of pulmonary TB disease.

\section{The effect of treatment compliance on recovery treatment of pulmona- ry TB in Mojokerto.}

There was a positive and direct effect of treatment compliance on recovery treat- 
Journal of Epidemiology and Public Health (2017), 2(2): 142-153

https://doi.org/10.26911/jepublichealth.2017.02.02.05

ment of pulmonary TB patients which was statistically significant. Treatment compliance would increase the possibility to recover. Patients with pulmonary TB who regularly take medication greatly affect their recovery. Patients who have treatment compliance were 4.3 times more likely to get negative smear results compared to non-adherent respondents (Kurniawan et $a l, 2015)$.

Treatment failure was caused by short periods of treatment, irregular treatment, and bad combination of the drugs (Golden, 2005). Theoretically, all sufferers can be cured, as long as the patient was regularly conduct the treatment until it was complete unless the bacteria was initially resistant to the OAT that was commonly used. If the patient did not take the medication regularly, the result was failure and multiresistant bacteria (Danusantoso, 2000).

Compliance was the patients behavior of both cognitively and intellectually who adhere to all the advice given by health personnels (Subhakti, 2014). Taking non-routine medication has been proven to cause drug resistance which could lead to treatment failure (Indonesian Lung Doctors Association, 2006).

It can be concluded that treatment compliance was affected by treatment recoverybecauseif pulmonary TB sufferers regularly took the medication and always adhere to the advice given by health personnels, it was likely that the sufferer can recover unless there were other factors such as being resistant to anti-tuberculosis drug. Conversely, if the patients did not adhere to the treatment, it could reduce the possibility of being able to recover and also the presence of bacteria that became resistant to the drug.

The recovery of pulmonary TB treatment was indirectly affected by educational level, family income, and family support through nutritional status and treatment compliance.

\begin{tabular}{l}
\hline REFERENCE \\
\hline Adriani M, Wirjatmadi B(2013). Pengantar \\
Gizi Masyarakat. Jakarta: Kencana \\
Prenada Media Group. \\
Amaliah R(2012). Faktor-faktor yang ber- \\
hubungan dengan kegagalan konversi \\
penderita TB paru BTA positif peng- \\
obatan fase intensif di Kabupaten \\
Bekasi Tahun 2010. Fakultas Kesehat- \\
an Masyarakat Universitas Indonesia. \\
http://lib.ui.ac.id/[Diaksespada tang- \\
gal 29 Januari 2017].
\end{tabular}

Currie CSM, Floyd K, Williams BG, Dye $\mathrm{C}(2005)$. Cost, affordability and costeffectiveness of strategies to control tuberculosis in countries with high HIV Prevalence. BMC Public Health, 5:130.

Danusantoso H (2000). Ilmu Penyakit Paru. Jakarta: Hippocrates.

East Java Health Office (2015). Profil Kesehatan Provinsi Jawa Timur 2014.

Mojokerto Health Office (2015). Profil Kesehatan Kota Mojokerto tahun 2014.

Erawatyningsih E, Purwanta, Subekti H (2009). Faktor-faktor yang mempengaruhi ketidakpatuhan berobat pada penderita tuberkulosis paru. Berita Kedokteran Masyarakat, 25(3): 117124.

GarciaIS, Blanco AR, Perez JLV, Viejo MAG, Hernandez MJJ, Lopez O, Asensio AN(2009). Risk factors for multidrug-resistant tuberculosis in a tuberculosis unit in Madrid, Spain. Eur J Clin Microbiol Infect Dis, 28: 325-330.

Golden MP, Vikram HR (2005). Extra-pulmonary tuberculosis: An Overview. American Family Physician, 72 (9). 
Hutapea TP (2009). Factors affecting compliance to medication in lung tuberculosis patients. Folia Medica Indonesiana, 45:45-49.

Indonesian Pulmonology and Respiratory Association (2006). Pedoman diagnosis \& penatalaksanaan tuberkulosis di Indonesia. Jakarta.

Kurniawan N, Rahmalia S, Indriati G (2015). Faktor-faktor yang mempengaruhi keberhasilan pengobatan tuberkulosis paru. JOM, 2: 729-741.

Ministry of Health (2013). Riset Kesehatan Dasar 2013. Badan Penelitian dan Pengembangan Kesehatan. Retrivied from http://labmandat.litbang.depkes.go.id/images/download/laporan/RKD/2013/Laporan_riskesdas_201 3_final.pdf. 29 January 2017.

Muna L, Soleha U (2014). Motivasi dan dukungan sosial keluarga mempengaruhi kepatuhan berobat pada pasien TB paru di Poli Paru Bp4 Pamekasan. Jurnal Ilmiah Kesehatan, 7(2):172179.

Murtantiningsih, Wahyono B (2010). Faktor-faktor yang berhubungan dengan kesembuhan penderita tuberkulosis paru. KEMAS, 6(1):44-50.

Nagarkar AK, Dhake D, Jha P (2012). Perspective of tuberculosis patient on family support and care in rural Maharashtra. Indian Journal of Tuberculosis, 59:224-230.

Nugroho RA (2011). Studi kualitatif faktor yang melatarbelakangi drop out pengobatan tuberkulosis paru. KEMAS, 7:83-90.

Nurmadya, MedisonI, Bachtiar H (2015). Hubungan pelaksanaan strategi directly observed treatment short course dengan hasil pengobatan tuberkulosis paru puskesmas Padang Pasir Kota padang 2011-2013. Jurnal Kesehatan Andalas, 4(1):207-211.
Phelan JC, Link BG, Tehranifar P (2010). Social conditions as fundamental causes of health inequalities: Theory, evidence, and policy implications. Journal of Health and Social Behavior, 51: 28-41.

Purwaningrum S, Wardani S (2012). Hubungan antara asupan makanan dan status kesadaran gizi keluarga dengan status gizi balita di wilayah kerja Puskesmas Sewon I Bantul. KES MAS, 6(3):144-211.

Ruditya DN (2015). Hubungan antara karakteristik penderita TB dengan kepatuhan memeriksakan dahak selama pengobatan. Jurnal Berkala Epidemiologi, 3(2):122-133.

Samuel B, Volkmann T, Cornelius S, Mukhopadhay S, Mejojose, Mitra K, Kumar AMV, et al(2016). Relationship between nutritional support and tuberculosis treatment outcomes in West Bengal, India. Journal of Tuberculosis Research, 4:213-219.

Silva VD, Tigeh S, Wirawan N, Made B (2016). The relationship between education, job, family income with TB medication dropouts in Timor-Leste. Bali Medical Journal, 5:97-100.

Subhakti KA (2014). Hubungan dukungan keluarga dengan tindakan penderita TB paru melakukan kontrol ulang di Puskesmas Sidomulyo. Pekanbaru: UR.Naskah asli tidak dipublikasikan.

Tirtana BT (2011). Faktor-faktor yang mempengaruhi keberhasilan pengobatan pada pasien tuberkulosis paru dengan resistensi obat tuberkulosis di Wilayah Jawa Tengah. Semarang: Universitas Diponegoro.

Wardlaw GM (2007). Perspective in Nutrition. Edisi ke-7. New York: McGrawHill.

Wirdani (2000). Hubungan keberadaan PMO dengan keteraturan minum 
Journal of Epidemiology and Public Health (2017), 2(2): 142-153

https://doi.org/10.26911/jepublichealth.2017.02.02.05

Obat Penderita TB di Kab. Pandeglang. Depok: UI

WHO (2014). Global Tuberculosis Report 2014. World Health Organization. retrieved from http://www.who.int/tb/publications/global_report/gtbr14 _main_text.pdf 5 February 2017.

WHO (2015). Sustainable development goals. World Health Organization.
Retrivied from http://www.who.int/mediacentre/events/meetings/2015/ un-sustainable-development-summit/en/ 5 February 2017.

WHO(2017). Global Tuberculosis Report 2016. World Health Organization. Retrieved from http://www.who.int/tb/publications/global_report/en/. January 2017 